\title{
Assistance of Amanah Farmer Women's Group in Increasing Product Value Added Through Packaging and Label Design in Limapuluh Kota Regency
}

\author{
Iis Ismawati' ${ }^{1}$ Raeza Firsta Wisra ${ }^{2}$, Imelfina Musthafa ${ }^{3}$, Riva Hendriani ${ }^{4}$ \\ ${ }^{1234}$ Program Studi Agribisnis Politeknik Pertanian Negeri Payakumbuh \\ E-mail: iesmawati08@gmail.com, alif aliya@yahoo.co.id, musthafa se@yahoo.com, \\ riva hendriani@yahoo.com
}

\begin{tabular}{ll}
\hline Article History: & Abstract: Amanah Farmer Women's Group (KWT) \\
Received: August 23rd 2020 & Amanah is one of the SME groups that processes \\
Revised: June $21^{\text {st }} 2021$ & cassava into tradisional snacks of West Sumatra. \\
Accepted: July $7^{\text {th }} 2021$ & Most products are sold wholesale, do not have \\
& labels and packaging, so the selling price is lower \\
& than the market price. The lack of knowledge of \\
Keywords: Packaging and & group members about the importance of product \\
Labelling, value added, Small & packaging and labels still an obstacle. The purpose \\
Medium Enterprise & of this community dedication is to provide \\
& awareness to the KWT Amanah community about \\
& the importance of labels and packaging in \\
& increasing product added value. In addition, the \\
& implementation team provided assistance in \\
& arranging P-IRT. The method used is trainning, \\
discussion, observation and demonstration. This & counseling activity provides insight and knowledge \\
that can motivate KWT Amanah to make decisions \\
in choosing the type of packaging used. This \\
community dedication program are improves value \\
added products through label designs, increase \\
members knowledge and create the products \\
selling value for partner.
\end{tabular}

\section{Introduction}

Limapuluh Kota Regency is one of the production centers of cassava in West Sumatera Province. It can produce 74.929 tons on average from 2013-2017[1]. The Increasing number of local tourists visiting Limapuluh Kota Regency tourism objects like Kawasan Wisata Lembah Harau, Panorama Kelok Sembilan dan Kapalo Banda has encouraged the emergence of souvenir shops selling snacks made of cassava. It indicates that the tourism sector can improve the multiplier effect of the growth of the business chain, creating employments and causing an impact on people's income within the regency[1]. Many of these souvenir shops stand along Jorong Ketinggian Nagari Sarilamak, Harau District. In general, the products come from several Small and Medium 
Enterprises (SMEs) scattered in the Limapuluh Kota Regency area. These SMEs process a lot of agricultural products into various snacks that have high added value. The food industry plays a very important role in fulfilling consumption needs and diversifying food. Therefore it is useful in supporting government programs to reduce the subjection of staple foods, as rice.

The Amanah Farmer Women's Group located in Nagari Taram, Harau District, includes SMEs. The products are various processed products made from cassava and caladium. There are at least ten product variants, namely original sanjai, ring sanjai balado, Long sanjai balado, karak Kaliang, plain sweet potato sticks, corn flavored sweet potato sticks, balado sweet potato sticks, sanjai karitiang, original karak Kaliang and barbeque flavored sweet potato sticks. Meanwhile, caladium is processed into Balado caladium chips. It is described that KWT Amanah has been able to differentiate products, but has not been able to diversify.

The strategic location near the popular tourist areas of Harau Valley and Kelok 9 is the strength of KWT Amanah's business to expand and promote their products. As the government guidance, the road infrastructure to tourism object in 2017, the number of tourists has increased. The data mentioned that the number of tourists was about 150.000 people until 2016. It significantly increased in 2018 to 403.620 people. It is expected that the number of sales of cassava products will be also increasing.

However, KWT Amanah faces a lot of problems in its production process. Such as the production equipment, especially for slicing cassava, which still uses a manual knife. Another problem is that the company does not yet have a grater to make Karak Kaliang. So far, the grating process is still rented from another company that already has a grating machine. In the marketing aspect, although the marketing area has reached outside the region (Harau Valley Tourism Area, Payakumbuh, Bukitinggi, Pekanbaru, and Dumai), the products are still sold wholesale. As a result, the selling price is still low.

From the results of observations and in-depth discussions with members, it can be seen that products are sold wholesale, packaged using 2 sizes of plastic. The first package with a capacity of $7 \mathrm{Kg}$ is sold for IDR 200,000 and a capacity of $10 \mathrm{Kg}$ is sold for IDR. 300,000. The price is much lower than the retail price at a food shop in a tourist area. Sebagai contoh produk yang sama dikemas ukuran 250 gram, dijual sekitar IDR 10.000-15.000. Meanwhile, in tourist shops, similar products are sold in retail that has been packaged with a price range between $\mathrm{Rp}$. 10,000-15,000/250 grams. There are KWT Amanah products that are sold in retail with the packaging of 1$0.25 \mathrm{Kg}$, but the proportion is still very small from the products sold wholesale. The retailed product also does not have a P-IRT license and also product label.

Whereas packaging has an important role in introducing products to consumers. As stated by Delgado et al. that packaging can influence consumers to make product purchases ${ }^{1}$. Where the color of the packaging and the image on the packaging play an

${ }^{1}$ Claudia Delgado, Aurora Gómez-Rico, and Jean Xavier Guinard, "Evaluating Bottles and Labels versus Tasting the Oils Blind: Effects of Packaging and Labeling on Consumer Preferences, Purchase Intentions and Expectations for Extra Virgin Olive Oil," Food Research International 54, no. 2 (2013): 2112-2121, http://dx.doi.org/10.1016/j.foodres.2013.10.021. 
important and significant role in encouraging consumers to buy the product ${ }^{2}$. If the motivation to buy increases, it is expected that the level of product sales will also increase. The results of the study conducted by Ifeanyi et al. stated that product packaging had a significant effect on increasing the number of bread sales for SMEs in Southeast Nigeria ${ }^{3}$.

Although packaging and labels are proven to be able to increase product sales, there are still many SMEs that have not prioritized them as a business development strategy. For example, food businesses (snacks) in Tangerang mostly use simple packaging without a brand. The packaging used is only to protect the product so that it is durable and easy to carry ${ }^{4}$. According to Alsuhendra and Ridawati, there are two causes of MSME products not using packaging and labels, namely (a) concerns about the high cost of manufacture and (b) lack of understanding and information about how to get attractive packaging and labels at affordable prices ${ }^{5}$.

Based on the explanation and problems faced by KWT Amanah above, it is necessary to engage and increase the value-added of their product, through training activities and assistance in developing packaging and labeling. The objectives of this activity are (1) to provide knowledge and understanding of the importance of packaging and labels in increasing the added value of various processed cassava products and (2) to assist KWT Amanah in choosing to package and making labels that are suitable for the product. The outcome of this activity is the growing awareness and knowledge of partners about the benefits of packaging and labels to increase product added value and the availability of attractive labels for partner products.

According to Alsuhendra and Ridawati, training and demonstrations on packaging and labels for food product SMEs are an effective way to increase the knowledge of the target group in making good food labels that meet the requirements. The same thing was also done by Maryama et.al, who conducts training in packaging making to increase sales of food MSME products in South Tangerang. The method of conducting lectures, discussions, demonstrations, practices, and observations is considered to increase participants' knowledge about the importance of packaging for food products

Assistance and empowerment are needed so that the knowledge that has been obtained can be applied by members of the partner group. The activities of empowering women's groups who are entrepreneurs are urgently needed. Because entrepreneurial women have an important impact on social, political, and economic empowerment. In

2 Nawaz Ahmad and Asad Lakhan, "Effect of Product Packaging in Consumer Buying Decision Research Statement: Literature Review:," Journal of Business Strategies 6, no. 2 (2012): 1-10, https://www.researchgate.net/publication/262291170_Effect_of_Product_Packaging_in_Consumer_Buyi ng_Decision.

${ }^{3}$ Chukwuma, Anthony Ifeanyi, Emma Ezenyilimba, and Vincent N.O. Aghara, "Effect of Product Packaging on the Sales Volume of Small and Medium Scale Bakery Firms in South East Nigeria," International Journal of Academic Research in Business and Social Sciences 8, no. 6 (2018): 988-1001.

4 Siti Maryama et al., "PEMBUATAN PACKAGING DALAM UPAYA," in SEMBADHA2018 Seminar

Hasil Pengabdian Kepada Masyarakat (PKN STAN Press, n.d.), 156-159, http://jurnal.stan.ac.id/index.php/sembadha/article/download/365/255.

${ }^{5}$ Alsuhendra dan Ridawati2, "Pelatihan Pembuatan Kemasan Dan Label Makanan Bagi” (2017), http://jurnaldianmas.org/index.php/Dianmas/issue/view/18. 
addition, Tjilen et al. consider that in general the empowerment and participation of women in the regions are still not optimal, even though these activities are important in regional development. So according to Carr et al., an integrated effort is needed in community empowerment programs, namely by carrying out comprehensive activities between education and training.

\section{Method}

Before assistance activities begin, problem identification and discussion declare. It is necessary so that the partner's expectations and the solutions offered by the Team are under the partner's wishes. It is a crucial stage, so as the solution's problems is the result of joint participation between the Team and partners. Because, occasionally the technology provided is less acceptable to user partners because the program is topdown, not bottom-up.

This community assistance activity was implemented at the Kelompok Wanita Tani Amanah located in Jorong Gantiang Nagari Taram, Harau District, Limapuluh Kota Regency in April-November 2019. The team consists of 4 lecturers from the Agribusiness Study Program. On the other hand, The KWT Amanah consists of 20 members. Activities are come on at the KWT Amanah secretariat, the location of the production site, and the marketplace of the stall. The timing of the activities is adjusted to the willingness of partners because in general partners are the wives of farmers whose main tasks are farming.

The implementation method is divided into three stages consisting of the preparation stage, implementation stage and evaluation (See figure 1) .

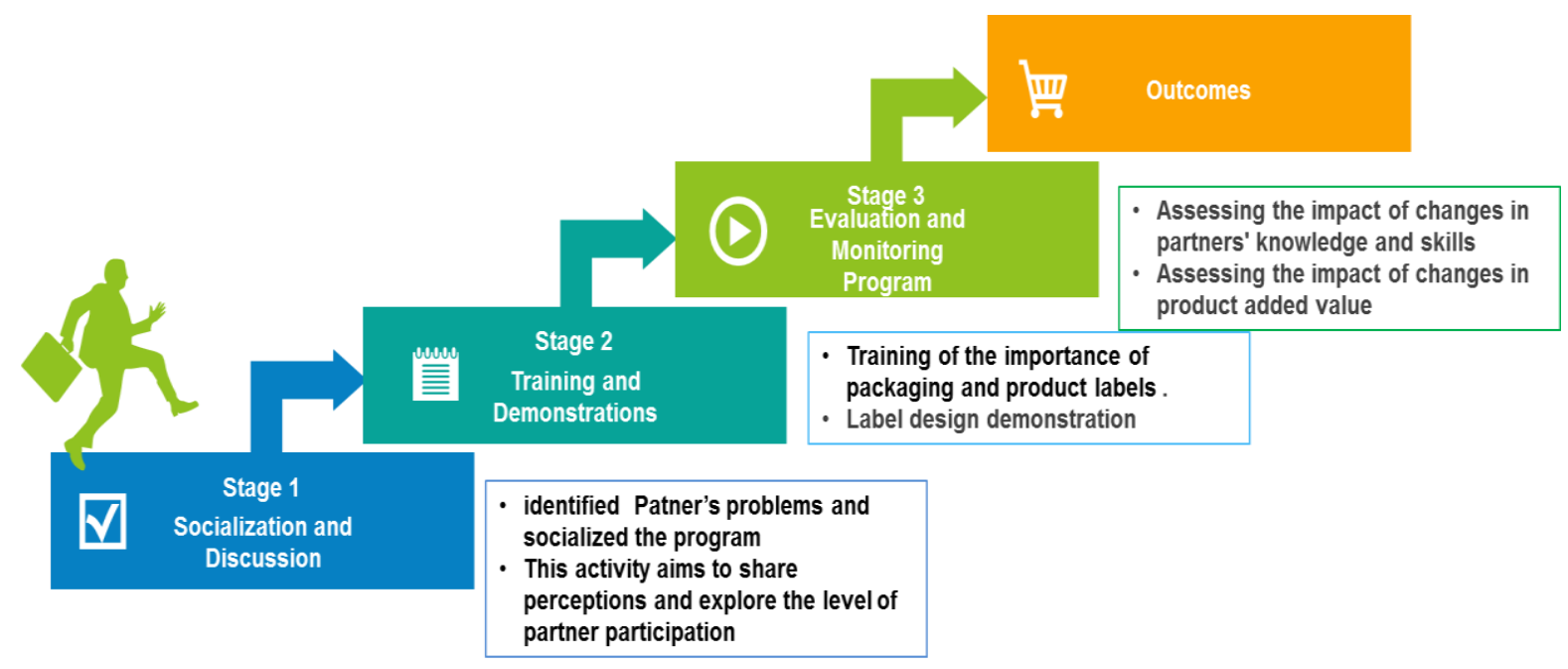

Figure 1. The Stage of Assistance Activity Program

The first stage is preparation, starting with program socialization, problem identification and discussion to find solutions. The selected solution is the result of a 
joint decision between the Team, and partners, Partner participation is needed to train partners' independence and ensure program sustainability. The second stage is partner assistance. The activities carried out were workshops on the role of SMEs packaging and good labels, demonstrations introducing various types of packaging from sanjai chips and other Minangkabau specialties. Then proceed with introducing the figure of a successful entrepreneur who produces Sanjai chips and has managed to package their products well. The activity ends with training to create the labels desaign, that are appropriate for partner products. The third stage is evaluation and monitoring.

The evaluation is important to analysis the partner's knowledge about the benefit of product labeling and packaging. Meanwhile, monitoring activities are objects to know the impact of service activities on increasing the added value of partner products. Through the analysis of the difference in the selling price of the product before and after being labeled.

\section{Result and Discussion}

\section{Socialization and Discussion}

Before the assistance activities, the team identified problems and socialized the program (Figure 2). This activity aims to share perceptions and explore the level of partner participation so that the program can achieve its goals optimally. The program had attended by 20 members of KWT Amanah and filled with discussions and questions-answers. Based on these activities, the marketing of various processed cassava and caladium products is still constrained because they do not have packaging and labels.
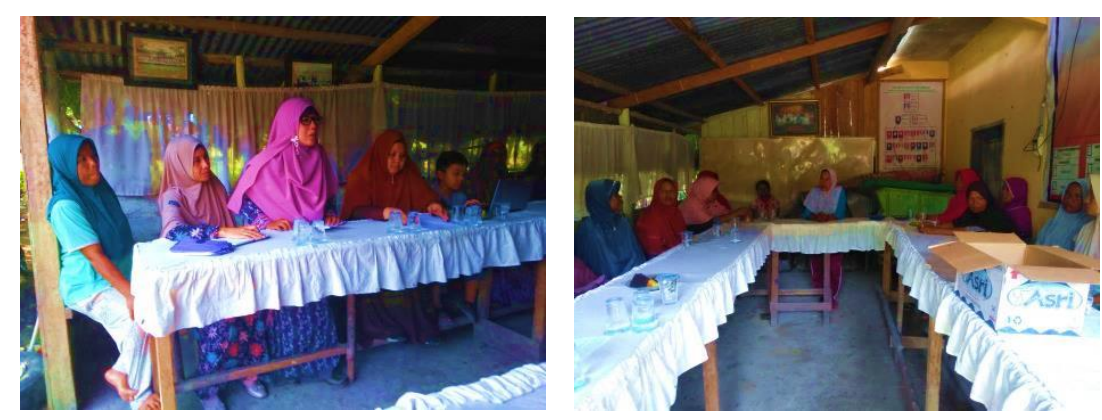

Gambar 1. Sosialisasi Kegiatan di KWT Amanah

The discussion result shows that partners' understanding of the purpose and benefits of packaging and labeling is still lacking. However, partners have a good comprehension of the importance of P-IRT licensing. The partner wishes to arrange for the P-IRT license immediately but does not yet have sufficient information on the procedure for processing it. Thus, the main focus of assistance KWT Amanah is to conduct training related to packaging and label development. Meanwhile, the required P-IRT permit is the management assistance activity 


\section{Training on the Importance of Labels- Packaging and Product Label Design Demonstration}

Most of the KWT Amanah products are sold in wholesale form by using a plastic size of 7 kilograms for chips and $10 \mathrm{~kg}$ for karak Kaliang. Retail sales are carried out in KWT member small shops, in plastic packaging, and tied with rubber (Figure 3). When viewed from the shape and taste, partner products are not inferior to similar products on the market. However, because it has not been packaged and labeled, it lacks product added value. So that outreach activities about labels and packaging are the right steps to overcome the problems faced by partners.

The theme of the training is the importance of packaging and product labels was carried out at the secretariat of KWT Amanah and had attended by 19 members. The high level of participation of group members shows their enthusiasm for the activities carried out. A combination of methods between lectures, discussions, and demonstrations is needed to attract trainees' participation.
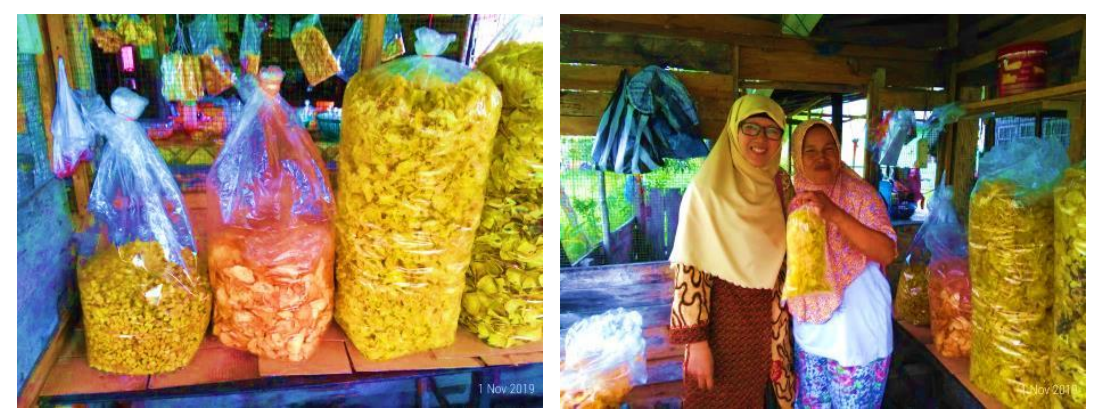

Figure 3. KWT Amanah Products: Various Chips and Sanjai

The label is one part of the product. In the form of a description of both pictures and words as a source of information. According to government regulation Number 69 of 1999 concerning food labels and advertisements, the information contained on the labels includes the brand, net weight/net content, name, and address of the party producing or importing food into the territory of Indonesia. In addition, other important information is raw materials, additional ingredients in the composition, nutritional information, expiration dates, product contents, and legality information. The purposes of labeling products include (1) providing information about the contents of the product without having to open the packaging, (2) means of communication between producers and consumers, (3) instructions to consumers to obtain optimum product functions, (4) advertising facilities for producers and (5) provide a sense of security to consumers.

Packaging is the activity of designing and producing packaging for a product. The functions of packaging are protection, attraction, promotional tool, transfer tool, and product brand image. Based on the structure of the contents, the types of packaging are divided into three, namely primary packaging, namely packaging materials that directly accommodate food ingredients, secondary packaging, namely packaging whose primary function is to protect other packaging groups, and tertiary and quaternary packaging, which are packaging needed to store or protect products during delivery. The types of food product packaging that can be used by SME businesses are vacuum 
bags, stand-up liquid pouches, stand-up zipper plastic, zipper pouches, stand-up combinations, pouch combinations, dull foil pouches.

In the demonstration activity, an introduction to the types of packaging was carried out by bringing examples of typical Minang souvenirs that have been widely marketed. In addition, it also describes the profile of entrepreneurs in Payakumbuh who produce various Balado, Sanjai, and Karak Kaliang. His business is growing after providing attractive packaging and labels on his products. At first, the entrepreneur thought that packaging and labels would only add to the cost of production. However, after being given understanding and assistance, the business is progressing and already has 2 gift shop outlets. By providing best practices like this, KWT Amanah members are more enthusiastic in participating in training activities. This can be seen from the many questions from the participants and interactive discussion.

The next activity is training to make food packaging and labels. Result of the discussion with partners, partners had chosen PP plastic for the product package. It is because the PP plastic price is relatively affordable. The limited capital is the main factor in assigning this packaging type. However, this packaging still keeps the product safe and durable. The choice of packaging type will affect the kind of label that can be design. Meanwhile, a common problem in rural areas is the low level of computer skills. The team guides the demonstration of the label design, while exploring the shapes, colors and designs that partners want.

"Amanah" is the specified brand, taken from the name of group. The color of the label is dominated by yellow with a combination of red. It is appropriate with the characteristic of the Minangkabau "Marawa" flag,consists of red, yellow, and black colors. The output of this assistance activity is the label design for KWT Amanah products, shown in Figure 4.
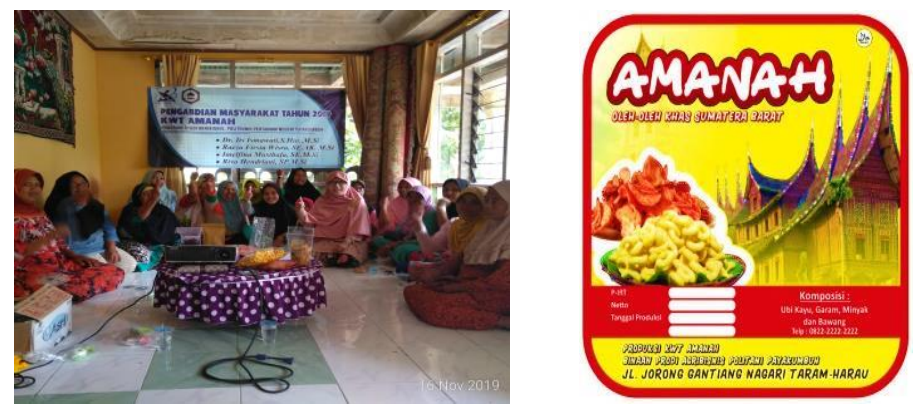

Figure 4. Training and Label Design Demonstration

The training activity is one of the efforts to provide KWT Amanah members with an understanding of the benefits of labels and packaging. In addition, it added value to the product to increase the competition in the market. The results of this knowledge transfer have broadened the knowledge of KWT members and raised awareness of the importance of packaging and labeling their products. After discussing and considering the condition of the capital owned, the type of packaging chosen by KWT Amanah is in the form of PP plastic is glued with a sealer machine. The Team recommends the use of colored wire tape as a packaging binder.

In accordance with the opinion of Qonita et al. the use of wire tape can be an 
alternative to rapia rope into tie cassava chip product plastic packaging. The use of colored wire tape makes the packaging more attractive and presentable[1]. However, the cost was one of the reasons why this option was not taken. This is in line with the opinion of Alsuhendra and Ridawati who stated that the causes of SMEs not using packaging and labels were limited costs, lack of understanding and information about attractive packaging and labels. ${ }^{3}$.

\section{Evaluation and Monitoring Program}

The evaluation activities aim to measure the partner's knowledge about the importance of labels and packaging. Partner members had assessed with the same questions, before and after the training. Open questions, which are asked consist of: (a) do you know the types of product packaging? (b) do you know what labels and information are (c) do you know the benefits of packaging and labels for producers and consumers.

The pre-assessment result shows that most partners do not know the types of packaging, labels, and benefits. Nearly 90 percent of partners answered that plastic is the kind of packaging for chips. But didn't know the type and size of plastic. Though the type of packaging is not only plastic. Question number two is about labels. Approximately $85 \%$ of partners answered that the label is a product brand, but did not know the important information that should be available on the label. The third question is about the benefits of packaging and labels. Nearly $95 \%$ of partners think that packaging and labels will only increase production costs and be less beneficial for the company.

Partners' awareness and knowledge about packaging and labeling increased after training and demonstrations. They are motivated to improve the added value of products through packaging and labels. Partners discuss with each other to decide the type of packaging. Based on the agreement between partners and consideration of limited capital, the selected product packaging is still plastic. The difference with the previous packaging, PP (Polypropylene) plastic is thicker. This packaging can increase the shelf life of the product. Products are packaged in sizes $1 / 4-1 / 2 \mathrm{Kg}$.

Monitoring activities carried out to monitor the development of partners' businesses. After the assistance activities, the selling value of partner products increased. Initially, product's partners usually sold in wholesale form, but now they have started to be packaged in retail at a higher price, as shown in Table 1 below.

Table. 1 Price Comparison of Partner Products Before and After Assistance

\begin{tabular}{lllc}
\hline \multirow{2}{*}{ Products } & Wholesale Price & \multicolumn{1}{c}{ Before } & \multicolumn{1}{c}{ After } \\
\cline { 3 - 4 } & & $\begin{array}{c}\text { Retail Price } \\
\text { Plastic PE } 1 / 4 \text { Kg }\end{array}$ & $\begin{array}{c}\text { Retail Price } \\
\text { Plastic PP 1/4 Kg + Labels }\end{array}$ \\
\hline Cassava Chips & IDR. 200.000/7kg & IDR.7250 & IDR. 8000-Rp. 10.000 \\
\hline Karak Kaliang & IDR. 300.000/10kg & IDR.7500 & IDR. 8000- Rp. 10.000 \\
\hline
\end{tabular}


Based on table 1, the assistance through training and demonstrations can have affected the knowledge and motivation of partners to develop their business. Partners become more aware of the benefits of using packaging and labels. The use of PE plastic packaging into PP can increase product durability. Referring to Yuniningsih et al who stated that training and mentoring of appropriate technology increase partner awareness in improving the quality of their products [1]. In addition, the use of packaging and labels can increase the selling value of partner products. If the product price has increased, the welfare of KWT Amanah members will be getting better. Both particular or as well as the village community in general.

According to feanyi et al., research, that product packaging has a significant effect on increasing the number of bread sales in SMEs in Southeast Nigeria. Another study was conducted by Kustyawati et al, which showed that labeling, packaging,and obtaining a P-IRT permit could increase coffee production by $19.1 \%$ in the Srikandi Multipurpose Business Group in Sidorejo Hamlet, Pekon Ngarip, Lampung. ${ }^{6}$

\section{Conclusion}

KWT Amanah's assistance through training on packaging and labels has succeeded in providing insight, awareness, and motivation for partners to increase the value-added of their products. In addition, there has been a change in behavior, where partners have been able to make decisions in choosing the type of package. Because partners' capital is still limited, PP type plastic is chosen as product packaging to replace PE type plastic. . Although the packaging used has not varied, but with the addition of labels on the product, it has been able to increase the selling value of the products.

This assistance activity has been going well and has provided benefits for partners. However, due to the limited implementation time, further assistance activities are needed in managing the P-IRT license. Thus the product label has a P-IRT number which will expand market reach and increase consumer confidence in the quality and safety of partner products. For this reason, the recommendation is indispensable to assist partners in terms of obtaining a product P-IRT license.

\section{Acknowledgements}

Thank you to the Center for Research and Community Service (P3M) of the Payakumbuh State Agricultural Polytechnic has funded the Community Service Program through PNBP funds for the 2019 fiscal year.

${ }^{6}$ Maria Erna Kustyawati et al., "Pemberdayaan Wanita Kelompok Serba Usaha Srikandi Melalui Diversifikasi Produk Kopi Bubuk Herbal," Riau Journal of Empowerment 2, no. 1 (2019): 15-20. 


\section{Reference}

Ahmad, Nawaz, and Asad Lakhan. "Effect of Product Packaging in Consumer Buying Decision Research Statement : Literature Review :" Journal of Business Strategies 6, no. 2 (2012): 1-10. https://www.researchgate.net/publication/262291170_Effect_of_Product_Packagi ng_in_Consumer_Buying_Decision.

Al-Dajani, Haya, and Susan Marlow. "Empowerment and Entrepreneurship: A Theoretical Framework." International Journal of Entrepreneurial Behaviour and Research 19, no. 5 (2013): 503-524.

Alsuhendra dan Ridawati2. "Pelatihan Pembuatan Kemasan Dan Label Makanan Bagi" (2017). http://jurnaldianmas.org/index.php/Dianmas/issue/view/18.

Carr, Alexis, Moses Tenywa, and K. Balasubramanian. "From Learning to Empowerment: A Study of Smallholder Farmers in South West Uganda." Journal of Learning for $\begin{array}{lllll}\text { Development } & 2, & \text { no. } & & \end{array}$ (2015): 15. https://files.eric.ed.gov/fulltext/EJ1107335.pdf.

Delgado, Claudia, Aurora Gómez-Rico, and Jean Xavier Guinard. "Evaluating Bottles and Labels versus Tasting the Oils Blind: Effects of Packaging and Labeling on Consumer Preferences, Purchase Intentions and Expectations for Extra Virgin Olive Oil." Food Research International 54, no. 2 (2013): 2112-2121. http://dx.doi.org/10.1016/j.foodres.2013.10.021.

Ifeanyi, Chukwuma, Anthony, Emma Ezenyilimba, and Vincent N.O. Aghara. "Effect of Product Packaging on the Sales Volume of Small and Medium Scale Bakery Firms in South East Nigeria." International Journal of Academic Research in Business and Social Sciences 8, no. 6 (2018): 988-1001.

Kustyawati, Maria Erna, Ribut Sugiharto, Sri Waluyo, and Erlina Erlina. "Pemberdayaan Wanita Kelompok Serba Usaha Srikandi Melalui Diversifikasi Produk Kopi Bubuk Herbal." Riau Journal of Empowerment 2, no. 1 (2019): 15-20.

Maryama, Siti, Pitri Yandri, Imal, and Istima. "PEMBUATAN PACKAGING DALAM UPAYA." In SEMBADHA2018 Seminar Hasil Pengabdian Kepada Masyarakat, 156159. PKN STAN Press, http://jurnal.stan.ac.id/index.php/sembadha/article/download/365/255.

Qonita et al. "Pemberdayaan Usaha Keripik Singkong Rasa Gadung” 7 (2018): 201-210. http://jurnaldianmas.org/index.php/Dianmas/issue/view/18.

Statistika, Badan Pusat. "Kabupaten Limapuluh Kota Dalam Angka" (2018). https://limapuluhkotakab.bps.go.id/publication/2018/08/16/513d7dc53d458b3 00cd82fa3/kabupaten-lima-puluh-kota-dalam-angka-2018.html.

Sudarsono, Heri, and Indah Susantun. "Pengembangan Potensi Wisata Di Kawasan 
Pantai Selatan Kabupaten Gunung Kidul, Yogyakarta." Agriekonomika 8, no. 1 (April 30, 2019): 81-92.

Tjilen, Alexander Phuk, Fitriani, Hesty Tambayong, Albertus Yosep Maturan, Samel Watina Ririhena, and Fenty Y. Manuhutu. "Participation in Empowering Women and the Potential of the Local Community Economy, a Case Study in Merauke Regency, Papua Province." International Journal of Mechanical Engineering and Technology 9, no. 167-176 167-176. http://www.iaeme.com/SearchResults.asp.

Yuniningsih, and Dwi Suhartini. "Pemberdayaan Perempuan Nelayan Melalui Pelatihan Pengolahan Hasil Ikan Menjadi Krupuk Bernilai Ekonomis Di Desa Gisikcemandi Kecamatan Sedati Kabupaten Sidoarjo." Engagement: Jurnal Pengabdian Kepada Masyarakat 2, no. 1 (2018): 51-61. 